Animal Production and Environment Received on: 10/02/2020

Accepted on: 23/06/2020

\title{
Effect of natural feed additives on meat quality and caecotrophic fatty acid profile of New Zealand rabbits
}

Efeito de aditivos alimentares naturais na qualidade de carne e no perfil de ácidos graxos cecotrófico de coelhos Nova Zelândia

\author{
NÓIA, Isabelle Zocolara ${ }^{1}$ \\ https://orcid.org/0000-0003-2896-9043 \\ GABRIEL, Andrea Maria de Araújo ${ }^{1}$ \\ https://orcid.org/0000-0002-8857-3721
}

FERNANDES, Alexandre Rodrigo Mendes $^{1}$

https://orcid.org/0000-0002-3697-9754

CÔNSOLO, Nara Regina Brandão² https://orcid.org/0000-0002-8389-7794
CARDOSO, Claudia Andrea Lima ${ }^{3}$

https://orcid.org/ 0000-0002-4907-0056

OLIVEIRA, Euclides Reuter ${ }^{1}$ https://orcid.org/0000-0001-6282-4855

GANDRA, Érika Rosendo de Sena ${ }^{4}$ https://orcid.org/0000-0002-4565-2817

GANDRA, Jefferson Rodrigues ${ }^{1 *}$ https://orcid.org/0000-0002-4134-5115

${ }^{1}$ Universidade Federal da Grande Dourados, Department of Animal Science, Dourados, Mato Grosso do Sul, Brazil.

${ }^{2}$ Universidade de São Paulo, Department of Animal Science, Faculdade de Zootecnia e Engenharia de Alimentos, Pirassununga, São Paulo, Brazil.

${ }^{3}$ Universidade Estadual de Mato Grosso do Sul, Chemistry Department, Unidade de Dourados, Dourados, Mato Grosso do Sul, Brazil.

${ }^{4}$ Universidade Federal do Sul e Sudeste do Pará, Instituto de Estudos do Trópico Úmido, Xinguara, Pará, Brazil.

*Corresponding author: jeffersongandra@ufgd.edu.br

\begin{abstract}
The objectives of this research were to evaluate the effects of commercial probiotic and chitosan as food additives on the quality and meat composition of 36 New Zealand White rabbits ( $57 \pm 8$ days old and $1,648 \pm 0.194 \mathrm{~kg})$ and on the fatty acid profile of caecotrophs. The treatments were CT (diets without inclusion of additives), PRO (inclusion of $4 \mathrm{~g} / \mathrm{kg}$ of commercial probiotic) and CHI (inclusion of $4 \mathrm{~g} / \mathrm{kg}$ of chitosan). The additives increased triglycerides and decreased urea compared to the control group, as well as increased oleic and linoleic acids, $\Sigma$ unsaturated, $\Sigma$ monounsaturated and $\Sigma$ polyunsaturated in caecotrophs. CHI animals showed a decrease in myristic and palmitic acids compared to PRO. CHI decreased the meat's crude protein and the meat's fat. In addition, there was a decrease in omega-3, omega- 6 and the relationship unsaturated and saturated fatty acids for the CHI group and an increase in erucic acid and a decrease in the rate of hypocholesterolemic acids. As a conclusion, the data showed that the animals that ingested probiotic had better meat quality, for having better fatty acid profile and hypocholesterolemic index, compared to the treatment with chitosan. The additives improved the caecotrophs fatty acid profile.
\end{abstract}


Keywords: chitosan, digestive health, microbial additive, probiotic, triglyceride

\section{RESUMO}

Os objetivos desta pesquisa foram avaliar os efeitos do probiótico e da quitosana como aditivos alimentares na qualidade e composição da carne de 36 coelhos da raça Nova Zelândia Branco ( $57 \pm 8$ dias de idade e $1.648 \pm 0.194 \mathrm{~kg})$ e no perfil de ácidos graxos dos cecotrofos. Os tratamentos foram CT (dietas sem inclusão de aditivos), PRO (inclusão de $4 \mathrm{~g} / \mathrm{kg}$ de probiótico) e CHI (inclusão de $4 \mathrm{~g} / \mathrm{kg}$ de quitosana). Os aditivos aumentaram os triglicerídeos e diminuíram a ureia em comparação ao grupo controle, bem como amentaram os ácidos oleico e linoleico, $\Sigma$ insaturados, $\Sigma$ monoinsaturados e $\Sigma$ poliinsaturados nos cecotrofos. Os animais CHI apresentaram diminuição nos ácidos mirístico e palmítico em comparação ao PRO. A CHI diminuiu a proteína bruta da carne e o extrato etéreo da carne. Além disso, houve uma diminuição no ômega-3, ômega-6 e a relação entre ácidos graxos insaturados e saturados para o grupo CHI e aumento do ácido erúcico e diminuição do índice de hipocolesterolemia. Como conclusão, os dados mostraram que os animais que ingeriram probiótico apresentaram melhor qualidade da carne, por apresentarem melhores perfil de ácidos graxos e índice hipocolesterolêmico, em comparação ao tratamento com quitosana. Os aditivos melhoraram o perfil de ácidos graxos dos cecotrofos.

Palavras-chave: aditivo microbiano, probiótico, quitosana, saúde digestiva, triglicerídeo

\section{INTRODUCTION}

In order to attempt the demand for the modern consumers' desire for a healthy lifestyle, rabbit meat can be an interesting source of high contents of polyunsaturated fatty acids, proteins, and essential amino acids (Li et al., 2018). Rabbit meat products have been rapidly developed during the last two decades, with an increased on the global rabbit meat production by $16 \%$ between 2010 2015 (FAOSTAT, 2015), and have become increasingly popular worldwide (Li et al., 2018).

To maximize the animal's growth some antibiotics has been use as growth promoters, it can improve feed efficiency, muscle growth and carcass weight (Falcão-e-Cunha et al., 2007). However, concerns were raised that the use of antibiotics for growth promotion could lead to a problem of increasing resistance in bacteria of human and animal origin, and risks to human health
(Falcão-e-Cunha et al., 2007; Yang et al., 2019). As consequence, there has been considerable effort by the scientific community and the animal feed industry to find alternatives to conventional antibiotics in meat production. In this sense, the investigation of natural alternatives free residues, such as probiotics and chitosan, has become important on animal production.

The probiotics has been largely reported in cattle, chicken and pigs (Ouwehand et al., 1999; Abdou et al., 2018). Generally, the probiotics mechanisms of action are reduction of metabolic reactions which produce toxic substances, stimulation of host enzymes, production of vitamins or antimicrobial substances, competition for adhesion to epithelial cells and an increased resistance to colonization, and stimulation of the immune system of the host (Falcão-e-Cunha et al., 2007)

Chitosan is one of the most abundant natural polysaccharide biopolymers. Over the few years, chitosan has 
received much attention due to its potential antimicrobial properties against bacteria, fungi, and yeasts (Raafat \& Sahl, 2009). Also, chitosan might alter fermentation at rumen and cecum for more energetically efficient patterns and may provide an alternative to antimicrobial growth promoters (Goiri et al., 2010; Araújo et al., 2015; Paiva et al., 2015). However, little had been done incorporate chitosan and probiotic as natural growth promoter in New Zealand white rabbits. Therefore, the aim of this study was to evaluate the effects of probiotic and chitosan addition to the diets on meat quality and caecotroph fatty acids profile of New Zealand white rabbits.

\section{MATERIAL AND METHODS}

All animal procedures used in this study were conducted in accordance with the Institutional Animal Care and Use Committee Guidelines of the Federal University of Grande Dourados and approved by the animal ethics committee (Protocol Number: 034/2107).
The feedlot study was conducted in Dourados, Brazilian Center-West region (latitude $22^{\circ} 13^{\prime} 18.54^{\prime \prime}$ South, longitude $54^{\circ} 48^{\prime} 23.09^{\prime \prime}$ West and an average altitude of $430 \mathrm{~m}$ ). The experiment lasted for 7 wks. which included 1 wk. adaptation period and 6 wks. experimental period.

Thirty-six New Zealand White rabbit male with $57 \pm 8$ days age and an average body weight (ABW) of $1.648 \mathrm{~kg} \pm 0.194$ were housed in individual cages $(40 \mathrm{~cm}$ length $\mathrm{x} 60 \mathrm{~cm}$ width $\mathrm{x} 45$ height) with ad libitum access to feed and water. During the trials, rabbits were housed in a ventilated building in which the maximum temperature was $25^{\circ} \mathrm{C}$ and the relative humidity ranges from $50 \%$ to $60 \%$. A cycle of $12 \mathrm{~h}$ of light and $12 \mathrm{~h}$ of dark was used throughout this trial. The diet used was a commercial formulate based on alfalfa hay, soybean meal, and mineral premix, with $18 \%$ of crude protein, $12 \%$ of crude fiber and 2.6 $\mathrm{Kcal} / \mathrm{g}$ of digestible energy (Table 1 ). The diameter of the pellets was $4 \mathrm{~mm}$.

Table 1. Chemical composition of the commercial basal diet offered to rabbits

\begin{tabular}{ll}
\hline Nutrient & Content \\
\hline Dry matter & $870.0 \mathrm{~g} / \mathrm{kg}$ \\
Crude protein & $140.00 \mathrm{~g} / \mathrm{kg}$ \\
Organic matter & $850.0 \mathrm{~g} / \mathrm{kg}$ \\
Fat & $30 \mathrm{~g} / \mathrm{kg}$ \\
Crude Fiber & $260.0 \mathrm{~g} / \mathrm{kg}$ \\
Neutral detergente fiber & $225.0 \mathrm{~g} / \mathrm{kg}$ \\
Acid detergente fiber & $180.0 \mathrm{~g} / \mathrm{kg}$ \\
Ash & $150.0 \mathrm{~g} / \mathrm{kg}$ \\
Calcium & $15.0 \mathrm{~g} / \mathrm{kg}$ \\
Phosphor & $6.0 \mathrm{~g} / \mathrm{kg}$ \\
Sodium & $2.2 \mathrm{~g} / \mathrm{kg}$ \\
Copper & $15.00 \mathrm{mg} / \mathrm{kg}$ \\
Manganese & $40.00 \mathrm{mg} / \mathrm{kg}$ \\
Zinc & $65.00 \mathrm{mg} / \mathrm{kg}$ \\
Cobalt & $1.00 \mathrm{mg} / \mathrm{kg}$ \\
Selenium & $1.00 \mathrm{mg} / \mathrm{kg}$ \\
Vitamin A & $10.000 .00 \mathrm{UI} / \mathrm{kg}$
\end{tabular}




\begin{tabular}{ll} 
Vitamin D3 & $1.2000 .00 \mathrm{UI} / \mathrm{kg}$ \\
Vitamin E & $20.00 \mathrm{UI} / \mathrm{kg}$ \\
Lysine & $6.00 \mathrm{~g} / \mathrm{kg}$ \\
Methionine & $2.00 \mathrm{~g} / \mathrm{kg}$ \\
\hline Fatty acids $(\mathrm{g} / 100 \mathrm{~g})$ & \\
\hline C $16: 0$ & 11.35 \\
C $16: 1$ & 2.43 \\
C $18: 0$ & 5.21 \\
C $18: 1$ & 23.31 \\
C $18: 2$ & 48.45 \\
C $18: 3$ & 6.21 \\
\hline
\end{tabular}

Upon arrival, rabbits were weighed, and distributed in a completely randomized design in three groups according treatments: CT) diets with no additives inclusion; PRO) Inclusion of $4 \mathrm{~g} / \mathrm{kg}$ of probiotic (Equisflora ${ }^{\circledR}$ Kera Nutrição Animal, Bento Gonçalves-RS; composition: Bifidobacterium bifidum $5 \times 10^{8}$ ufc $\mathrm{g}^{-1}$; Enterococcus faecium $5 \times 10^{8}$ ufc g $^{-1}$; Lactobacillus casei $5 \times 10^{8}$ ufc $\mathrm{g}^{-1}$; Pediococcus acidilactici $5 \times 10^{8}$ ufc $\mathrm{g}^{-1}$; Saccharomyces cerevisiae $10 \times 10^{9} \mathrm{ufc} \mathrm{g}^{-1}$ ) on diet dry matter (DM); CHI) Inclusion of $4 \mathrm{~g} / \mathrm{kg}$ of chitosan (Polymar Industria e Cia. Imp. and Exp. Ltda., Ceará, Brazil; technical specifications: density of $0.64 \mathrm{~g} \mathrm{~mL}-1$, $20 \mathrm{gkg}-1$ of ash, 7.0-9.0of $\mathrm{pH}$, viscosity $<200 \mathrm{cPs}$, and deacetylation level of $95 \%$ ) on diet DM. Animals were allocated in individual cages (12 pens per treatment).

Feeds were provided twice daily, at 08:00 $\mathrm{h}$ and 14:00 $\mathrm{h}$ and the residual feed in the raising cages was collected daily for adjusted the daily offer according to the weight of the leftovers, to allow a minimum of $3 \%$ and a maximum of $5 \%$ of orts. The additives were included in the mineral premix and to the pellet mixture.

Blood samples were collected at the beginning and at the end of additives supplementation by puncture of the aorta vein or artery prior to the morning feeding. Blood samples $(10 \mathrm{~mL})$ were collected into 10-mL tubes (BD Vacutainer, São Paulo, SP, Brazil), without anticoagulant, for the measurement of serum glucose, cholesterol, triacylglycerol, total protein, and serum urea. Serum metabolites were analyzed calorimetrically according to standard procedures using commercially available diagnostic kits (Randox Laboratories, São Paulo, SP, Brazil) in an ABS-200 automatic biochemistry analyzer (CELM, São Caetano do Sul, SP, Brazil).

For caecotroph lipid profile, samples of caecotroph were taken at day 15,30 and 45 of the experimental period. The light plastic collars at $25 \mathrm{~cm}^{2}$ were put on the animals at 09:00 to prevent caecotroph. Caecotroph sampling was performed at 14:00, 18:00 and 09:00 of the next day (after $24 \mathrm{~h}$ ), when the collars were removed from the animals. For each rabbit an amount of fresh caecotroph was immediately used to determine DM content and the remaining was freezedried.

After 60 days on feedlot, rabbits were electrically stunned $(70 \mathrm{~V}$, pulsed direct current, $50 \mathrm{~Hz}$ for $5 \mathrm{~s}$ ) and killed by cervical dislocation. After $24 \mathrm{~h}$ postmortem the carcass $\mathrm{pH}$ was recorded and samples from Longissimus lumborum (LL) were taken for color, water holding capacity (WHC), cooking loss (CL), Warner Bratzler Shear Force (WBSF), and proximate analysis. The 
color was measure using a Minolta CR $200 \mathrm{~b}$ in the $\mathrm{L}^{*}, \mathrm{a}^{*}$ and $\mathrm{b}^{*}$ system. $\Delta \mathrm{E}$ was calculated to check if there is a difference between the color of the meat according to Technical Report Colorimetry (CIE, 2004), using the formula $\Delta \mathrm{E}=\left(\left(\Delta \mathrm{a}^{*}\right)^{2}+\left(\Delta \mathrm{b}^{*}\right)^{2}+(\Delta \mathrm{L})^{2}\right.$ )$^{0.5}$, when $\Delta \mathrm{a}, \Delta \mathrm{b}$ and $\Delta \mathrm{L}$ are, respectively, the variation between the values of the reddish, yellowish and luminosity variables of the standard and those obtained through the readings of the Minolta equipment. Perceptible difference to the human eye was considered $\Delta \mathrm{E}>2.3$ units, according to Mancini et al. (2019).

The water holding capacity was determined according to Torres (2005). The $3.0 \mathrm{~g}$ meat samples was subjected to compression by $2.25 \mathrm{~kg}$ standard weight, for five minutes. Meat chemical composition was determined in all samples (triplicate). Meat was thawed over the night before analysis, minced, and homogenized to determine moisture, ash, crude protein (CP), and extract ethereo (EE) (AOAC, 2000).

The WBSF and CL were determined according the methodology proposed by (Wheeler et al., 2005). The LL samples were thawed for $24 \mathrm{~h}$ at $4{ }^{\circ} \mathrm{C}$, weighed, and roasted in an oven equipped with a thermostat adjusted to $170{ }^{\circ} \mathrm{C}$ (Flexa de Ouro Industry, São Paulo, SP, Brazil). The steaks internal temperature was monitored using individual thermometers (Globo Industry, Americana, SP, Brazil) until it reached $71^{\circ} \mathrm{C}$. The samples were cooled to $28^{\circ} \mathrm{C}$ and weighed again, thus obtaining the value for CL. Steaks were cooled at $4{ }^{\circ} \mathrm{C}$ for $24 \mathrm{~h}$ before shearing. For WBSF evaluation, cores with $1.3 \mathrm{~cm}$ of diameter were taken from each steak, parallel to the orientation of the muscle fibers. Each core was sheared perpendicular to the muscle fiber using a WBSF instrument (Warner-Bratzler meat Shear, G-R Manufacturing, Collins, KS, USA), according to standard procedures from American Meat Science Association (AMSA, 1995). The WBSF values of the six subsamples were averaged for statistical analysis.

To proximate analyses, $2 \mathrm{~g}$ of $L L$ were sampled after 24 hours' postmortem to evaluate DM, ash, CP and EE. The DM was analyzed by the method 950.15 (AOAC, 2000), samples were weighed out into pre-dried, pre-weighed containers and allowed to dry for $18 \mathrm{~h}$ at $100^{\circ} \mathrm{C}$ in an air oven. The samples were cooled and weighed to obtained DM value. Ash was evaluated by the method 942.05 (AOAC, 2000). Samples were weighed into pre-dried, pre-weighed crucibles and placed into a specific oven at $550^{\circ} \mathrm{C}$ for $24 \mathrm{~h}$. Samples were cooled in a desiccator and weighed.

Crude protein was determined using the AOAC (2000) $\mathrm{N} \times 6.25$; method 984.13 . Total nitrogen was determined with a furnace temperature of $1050^{\circ} \mathrm{C}$ with helium as the carrier gas as previously described by (Wahrmund-Wyle et al., 2000). Crude protein levels were determined by multiplying total nitrogen by a factor of 6.25 .

The EE were also analyzed according AOAC (2000) method 920.39. Samples were homogenized with $20 \mathrm{~mL}$ chloroform: methanol $(2: 1)$ in a $50 \mathrm{~mL}$ screw cap polypropylene tube. The homogenate was filtered through a Buchner funnel with slight suction as previously described by WahrmundWyle et al. (2000). The filter was rinsed with chloroform: methanol. The filtrate was transferred back into the $50 \mathrm{~mL}$ tube, and $8 \mathrm{~mL}$ of a $0.74 \% \mathrm{KC} 1$ solution was added. After separation, the upper phase was siphoned off, and the lower phase was transferred into pre-dried, preweighed beakers. 
To determine the meat and caecotroph fatty acid profile, samples were saponified, and the fatty acids were extracted and methylated using the method of Hara \& Radin (1978) and Christie (1982). The fatty acid profile was analyzed by gas chromatography (Thermo Finnigan, Trace 2000) using an SP-2560 silica capillary column $(100 \mathrm{~m}$ $\times 0.25 \mathrm{~mm}$ in diameter with $0.02 \mathrm{~mm}$ thickness, Supelco, Bellefonte, PA). One standard (CRM-164, Commission of the European Communities, Community Bureau of Reference, Brussels, Belgium) was used to identify the fatty acids.

Data were submitted to analysis of variance using the PROC MIXED (version 9.3, SAS Institute, Cary, NC), according to the following model:

$$
Y_{i j}=\mu+A_{i}+T_{j}+e_{i j}
$$

with $e_{i j k} \approx N\left(0, \sigma_{i}^{2}\right)$; where $Y_{i j k}$ is the value of dependent variable, $\mu$ is the overall mean, $A_{i}$ is the fixed effect of animals ( $\mathrm{i}=1$ to 24$), T_{j}$ is the fixed effect of treatment ( $\mathrm{j}=1$ to 3 ), $e_{i j}$ is the residual error, $N$ stands for Gaussian distribution, and $\sigma_{i}^{2}$ is the variance associated with each treatment. Degrees of freedom were corrected by Kenward and Rogers (1997) method. The effect of treatments was decomposed into orthogonal contrasts: (1) control vs. additives and (2) chitosan vs. probiotic. Other comparisons were made using Fisher's protected LSD. Significance level was set at $\mathrm{P}<0.05$ and tendence at $\mathrm{P}<0.10$.

\section{RESULTS}

Initial body weight (BW) was similar for the treatments, demonstrating homogeneity at the initial allocation (Table 1). The inclusion of feed additives in the diet did not change (contrast $1 ; \mathrm{P}>$ 0.05 ) final body weight and dry matter intake. According serum metabolites, the additives increased $(\mathrm{P}=0.001)$ the triglycerides by $31 \%$ and decreased $(\mathrm{P}=$ 0.023 ) urea by $6 \%$ compared to control group (Table 1). When additives were compared between each other, the chitosan increased $(\mathrm{P}=0.032)$ by $30 \%(\mathrm{P}$ $=0.032)$ and by $21 \%(\mathrm{P}=0.013)$ the serum glucose and triglycerides, and increased by $8,5 \%(\mathrm{P}=0.016)$ the cholesterol compared with animals fed PRO diet. Also, there was no effect of treatments $(\mathrm{P}>0.05)$ on serum total protein concentration between treatment (Table 2).

Table 2. Effects of probiotic and chitosan on body weight and blood parameters of New Zealand white rabbits.

\begin{tabular}{|c|c|c|c|c|c|c|}
\hline \multirow{2}{*}{ Item } & \multicolumn{3}{|c|}{ Diet $^{A}$} & \multirow{2}{*}{ SEM } & \multicolumn{2}{|c|}{$P-$ Value ${ }^{B}$} \\
\hline & $\mathrm{CT}$ & PRO & QUI & & $\mathrm{C} 1$ & $\mathrm{C} 2$ \\
\hline \multicolumn{7}{|c|}{ Body weight (kg) } \\
\hline Inicial & 1.73 & 1.62 & 1.67 & 0.03 & 0.425 & 0.578 \\
\hline Final & 2.50 & 2.64 & 2.64 & 0.05 & 0.273 & 0.995 \\
\hline \multicolumn{7}{|c|}{ Blood parameters } \\
\hline Glucose (mg/dL) & 118.0 & 129.2 & 90.0 & 0.62 & 0.541 & 0.032 \\
\hline Cholesterol (mg/dL) & 168.5 & 155.7 & 169.0 & 0.88 & 0.411 & 0.013 \\
\hline $\begin{array}{l}\text { Triacylglycerols } \\
(\mathrm{mg} / \mathrm{dL})\end{array}$ & 103.2 & 151.5 & 119.5 & 1.78 & 0.001 & 0.016 \\
\hline Total protein $(\mathrm{g} / \mathrm{dL})$ & 7.90 & 8.12 & 8.65 & 0.45 & 0.113 & 0.216 \\
\hline $\operatorname{Albumin}(\mathrm{g} / \mathrm{dL})$ & 3.06 & 3.22 & 3.28 & 0.89 & 0.247 & 0.792 \\
\hline $\operatorname{Urea}(\mathrm{mg} / \mathrm{dL})$ & 47.6 & 43.0 & 43.8 & 0.98 & 0.023 & 0.628 \\
\hline
\end{tabular}

${ }^{\mathrm{A}}$ Diets: CT, control, with no additives inclusion; PRO, diet with $4 \mathrm{~g} / \mathrm{kg}$ of DM of probiotic inclusion; CHI, diet with $4 \mathrm{~g} / \mathrm{kg}$ of DM of chitosan inclusion 
${ }^{\mathrm{B}} \mathrm{C} 1$, contrast between $\mathrm{CT}$ and Additives; $\mathrm{C} 2$, contrast between PRO and $\mathrm{CHI}$.

There were an increased on oleic $(\mathrm{P}=$ $0.018)$ and linoleic acids $(P=0.013)$ in caecotroph from rabbits fed additives compared to the CT group (Table 2), consequently, the $\Sigma$ unsaturated $(\mathrm{P}=$ 0.003), $\Sigma$ monounsaturated $(\mathrm{P}=0.013)$, and $\Sigma$ polyunsaturated $(\mathrm{P}=0.006)$ was also increased by additives compared to the CT diet (Table 2). When the CHI and PRO were compared, there was a decrease on myristic $(\mathrm{P}=0.006)$ and palmitic $(\mathrm{P}=0.043)$ for $\mathrm{CHI}$ animals, then PRO group, with no effect $(\mathrm{P}>$ 0.05 ) for other caecotroph fatty acids evaluated (Table 3).

Table3. Effects of probiotic and chitosan on caecotroph fatty acid profile of New Zealand white rabbits

\begin{tabular}{|c|c|c|c|c|c|c|c|}
\hline \multirow{2}{*}{ Fatty acids $(\mathrm{g} / 100 \mathrm{~g})$} & \multirow{2}{*}{$\begin{array}{l}\text { Chain } \\
\text { length }\end{array}$} & \multicolumn{3}{|c|}{$\operatorname{Dieta}^{\mathrm{A}}$} & \multirow{2}{*}{ SEM } & \multicolumn{2}{|c|}{$P-$ Value $^{B}$} \\
\hline & & $\mathrm{CT}$ & PRO & QUI & & $\mathrm{C} 1$ & $\mathrm{C} 2$ \\
\hline Myristic & C 14:0 & 2.08 & 2.10 & 2.06 & 0.005 & 0.927 & 0.006 \\
\hline Palmitic & C 16:0 & 26.50 & 26.51 & 26.57 & 0.020 & 0.411 & 0.043 \\
\hline Palmitoleic & C $16: 1$ & 2.38 & 2.39 & 2.37 & 0.005 & 0.991 & 0.368 \\
\hline Stearic & C 18:0 & 11.02 & 11.04 & 11.06 & 0.011 & 0.243 & 0.354 \\
\hline Oleic & C $18: 1$ & 25.53 & 25.61 & 25.64 & 0.018 & 0.018 & 0.423 \\
\hline Linoleic & C $18: 2$ & 29.55 & 29.65 & 29.67 & 0.017 & 0.013 & 0.390 \\
\hline Linolenic & C $18: 3$ & 0.939 & 0.939 & 0.947 & 0.006 & 0.782 & 0.682 \\
\hline Arachidonic & C 20:0 & 0.174 & 0.175 & 0.175 & 0.001 & 0.869 & 0.946 \\
\hline Eicosanoic & C 20:1 & 0.235 & 0.238 & 0.231 & 0.001 & 0.767 & 0.785 \\
\hline Behenic & C 22:0 & 0.242 & 0.242 & 0.243 & 0.001 & 0.966 & 0.356 \\
\hline Erucic & C $22: 1$ & 0.780 & 0.768 & 0.789 & 0.006 & 0.898 & 0.189 \\
\hline$\Sigma$ saturated & - & 40.02 & 40.07 & 40.12 & 0.024 & 0.233 & 0.273 \\
\hline$\Sigma$ unsaturated & - & 59.42 & 59.59 & 59.65 & 0.030 & 0.003 & 0.221 \\
\hline$\Sigma$ monounsaturated & - & 28.94 & 29.00 & 29.04 & 0.017 & 0.013 & 0.357 \\
\hline$\Sigma$ polyunsaturated & - & 30.48 & 30.58 & 30.61 & 0.017 & 0.006 & 0.656 \\
\hline UFA/SFA & - & 1.48 & 1.48 & 1.48 & 0.001 & 0.547 & 0.869 \\
\hline Total & - & 99.55 & 99.56 & 99.59 & 0.028 & 0.652 & 0.987 \\
\hline
\end{tabular}

${ }^{\mathrm{A}}$ Diets: CT, control, with no additives inclusion; PRO, diet with $4 \mathrm{~g} / \mathrm{kg}$ of DM of probiotic inclusion; $\mathrm{CHI}$, diet with $4 \mathrm{~g} / \mathrm{kg}$ of DM of chitosan inclusion

${ }^{\mathrm{B}} \mathrm{C} 1$, contrast between $\mathrm{CT}$ and Additives; $\mathrm{C} 2$, contrast between PRO and $\mathrm{CHI}$.

Rabbits fed with additives showed a tendency $(\mathrm{P}=0.09)$ for higher values of meat $b^{*}$, greater $(P=0.007)$ meat luminosity and an increase of $14 \%(\mathrm{P}=$ 0.02) in CL compared to the CT group (Table 3). In addition, redness was affected by the additives, in which lower values for $\mathrm{CHI}$ treatment compared to PRO were detected. When analyzing the data of $\Delta \mathrm{E}$, it was possible to verify that the color difference was greater in the meat of the rabbits that ingested the additives, in relation to $\mathrm{TC}(\mathrm{P}=0.012)$. In addition, the $\mathrm{CHI}$ animals had a decrease $(\mathrm{P}=0.01)$ in the CL by $10.2 \%$ and a tendency $(\mathrm{P}=0.07)$ for lower WBSF. In addition, there were no effects $(\mathrm{P}>0.05)$, between treatments, for the meat's water retention capacity and $\mathrm{pH}$ (Table 3). According proximate analysis, there was no effect of additives compared to the CT group (contrast 1); however, CHI decrease the meat crude protein by 
$23.3 \%$ and the ether extract by $13.8 \%$

compared to PRO group (Table 4).

Table 4. Effects of probiotic and chitosan on meat quality and composition of New Zealand white rabbits

\begin{tabular}{|c|c|c|c|c|c|c|}
\hline \multirow{2}{*}{ Item $^{\mathrm{A}}$} & \multicolumn{3}{|c|}{ Diet $^{\mathrm{C}}$} & \multirow{2}{*}{ SEM } & \multicolumn{2}{|c|}{$P$-Value ${ }^{D}$} \\
\hline & CT & PRO & CHI & & $\mathrm{C} 1$ & $\mathrm{C} 2$ \\
\hline \multicolumn{7}{|l|}{ Color $^{\mathrm{B}}$} \\
\hline$a^{*}$ & 1.43 & 1.38 & 0.61 & 0.19 & 0.370 & 0.052 \\
\hline$b^{*}$ & 1.60 & 2.93 & 2.03 & 0.25 & 0.090 & 0.264 \\
\hline $\mathrm{L}^{*}$ & 49.30 & 53.30 & 54.10 & 0.89 & 0.007 & 0.730 \\
\hline$\Delta \mathrm{E}$ & 49.35 & 53.40 & 54.14 & 0.92 & 0.012 & 0.547 \\
\hline $\mathrm{h}^{*}$ & 0.84 & 1.13 & 1.28 & 0.01 & 0.014 & 0.751 \\
\hline $\mathrm{C}^{*}$ & 1.99 & 1.51 & 0.61 & 0.02 & 0.031 & 0.124 \\
\hline WHC (\%) & 75.3 & 75.1 & 68.1 & 2.00 & 0.230 & 0.250 \\
\hline CL (\%) & 22.8 & 27.4 & 24.6 & 0.60 & 0.020 & 0.010 \\
\hline WBSF (kg) & 1.70 & 2.57 & 1.70 & 0.17 & 0.190 & 0.070 \\
\hline $\mathrm{pH}$ & 6.62 & 6.77 & 6.66 & 0.42 & 0.270 & 0.190 \\
\hline \multicolumn{7}{|c|}{ Proximate analyses (\% of DM) } \\
\hline Dry matter & 31.0 & 28.2 & 27.7 & 1.19 & 0.400 & 0.253 \\
\hline Mineral matter & 4.73 & 4.63 & 4.92 & 0.08 & 0.790 & 0.230 \\
\hline Crude protein & 13.2 & 15.0 & 11.5 & 0.75 & 0.970 & 0.010 \\
\hline Fat & 7.40 & 8.65 & 7.45 & 0.26 & 0.300 & 0.030 \\
\hline
\end{tabular}

${ }^{\mathrm{A}} \mathrm{WHC}$, water holding capacity; CL, cooking loss; WBSF, shear force.

${ }^{\mathrm{B}}$ The color analysis was performed after $24 \mathrm{~h}$ postmortem. $\mathrm{L}^{*}=$ Lightness; $\mathrm{a}^{*}=$ redness; $\mathrm{b}^{*}=$ yellowness; $\Delta \mathrm{E}=$ color difference.

${ }^{\mathrm{C}}$ Diets: CT, control, with no additives inclusion; PRO, diet with $4 \mathrm{~g} / \mathrm{kg}$ of DM of probiotic inclusion; $\mathrm{CHI}$, diet with $4 \mathrm{~g} / \mathrm{kg}$ of DM of chitosan inclusion

${ }^{\mathrm{D}} \mathrm{C} 1$, contrast between $\mathrm{CT}$ and Additives; $\mathrm{C} 2$, contrast between PRO and CHI.

Animals fed additives had a $17 \%$ decreased on arachidonic acid $(\mathrm{P}=$ $0.022)$, a $2 \%$ and $6.6 \%$ increased on behenic acid $(\mathrm{P}=0.032)$ and erucic acid $(\mathrm{P}=0.025)$, respectively, compared to the CT group (Table 4). There was a decreased $(\mathrm{P}=0.045)$ on linoleic acid on meat from animals fed $\mathrm{CHI}$ compared to
PRO diet, as consequence the Omega-6 $(\mathrm{P}=0.045)$ and USF/SFA $(\mathrm{P}=0.071)$ ratio were also decreased for $\mathrm{CHI}$ animals compared to the PRO group. Also, $\mathrm{CHI}$ increased erucic acid $(\mathrm{P}=$ 0.017) and decreased the hypocholesterolemia index $(\mathrm{P}=0.031)$ compared to rabbits fed PRO (Table 5). 
Table 5. Effects of probiotic and chitosan on meat fatty acid profile of New Zealand white rabbits.

\begin{tabular}{|c|c|c|c|c|c|c|c|}
\hline \multirow{2}{*}{ Fatty acids $(\mathrm{g} / 100 \mathrm{~g})$} & \multirow{2}{*}{$\begin{array}{l}\text { Chain } \\
\text { length }\end{array}$} & \multicolumn{3}{|c|}{$\operatorname{Diet}^{\mathrm{A}}$} & \multirow{2}{*}{ SEM } & \multicolumn{2}{|c|}{$P-$ Value $^{B}$} \\
\hline & & $\mathrm{CT}$ & PRO & QUI & & $\mathrm{C} 1$ & $\mathrm{C} 2$ \\
\hline Myristic & C 14:0 & 2.07 & 2.06 & 2.07 & 0.008 & 0.804 & 0.767 \\
\hline Palmitic & C 16:0 & 25.9 & 25.8 & 25.8 & 0.012 & 0.112 & 0.477 \\
\hline Palmitoleic & C $16: 1$ & 2.48 & 2.51 & 2.46 & 0.010 & 0.701 & 0.166 \\
\hline Stearic & C 18:0 & 11.2 & 11.1 & 11.2 & 0.014 & 0.711 & 0.143 \\
\hline Oleic & C $18: 1$ & 25.8 & 25.8 & 25.8 & 0.017 & 0.979 & 0.456 \\
\hline Linoleic & C $18: 2$ & 30.1 & 30.2 & 30.1 & 0.013 & 0.233 & 0.045 \\
\hline Linolenic & C $18: 3$ & 0.89 & 0.90 & 0.89 & 0.005 & 0.434 & 0.451 \\
\hline Arachidonic & C 20:0 & 0.17 & 0.10 & 0.18 & 0.002 & 0.022 & 0.636 \\
\hline Eicosanoic & C 20:1 & 0.24 & 0.24 & 0.23 & 0.001 & 0.661 & 0.453 \\
\hline Behenic & C 22:0 & 0.24 & 0.24 & 0.25 & 0.002 & 0.032 & 0.356 \\
\hline Erucic & C $22: 1$ & 0.75 & 0.75 & 0.85 & 0.003 & 0.025 & 0.017 \\
\hline$\Sigma$ saturated & - & 39.6 & 39.5 & 39.6 & 0.018 & 0.640 & 0.255 \\
\hline$\Sigma$ unsaturated & - & 60.3 & 60.4 & 60.3 & 0.021 & 0.348 & 0.031 \\
\hline$\Sigma$ monounsaturated & - & 29.3 & 29.3 & 29.3 & 0.015 & 0.835 & 0.661 \\
\hline$\Sigma$ polyunsaturated & - & 31.0 & 31.1 & 31.0 & 0.014 & 0.185 & 0.029 \\
\hline Total & - & 98.5 & 98.5 & 98.5 & 0.001 & 0.062 & 0.712 \\
\hline Omega-3 & - & 0.89 & 0.90 & 0.89 & 0.005 & 0.434 & 0.451 \\
\hline Omega-6 & - & 30.1 & 30.2 & 30.1 & 0.013 & 0.233 & 0.045 \\
\hline Omega-9 & - & 26.8 & 26.8 & 26.8 & 0.017 & 0.994 & 0.520 \\
\hline UFA/SFA & - & 1.12 & 1.13 & 1.12 & 0.001 & 0.178 & 0.071 \\
\hline Omega-3/Omega-6 & - & 48.4 & 47.7 & 48.0 & 0.298 & 0.488 & 0.542 \\
\hline Hipercolesterolemics & - & 28.0 & 27.9 & 27.9 & 0.015 & 0.163 & 0.660 \\
\hline Hipocolesterolemics & - & 60.3 & 60.4 & 60.3 & 0.020 & 0.348 & 0.031 \\
\hline Hiper/Hipo & - & 0.66 & 0.66 & 0.66 & 0.001 & 0.423 & 0.437 \\
\hline $\begin{array}{l}\text { Thrombogenicity } \\
\text { index }\end{array}$ & - & 0.69 & 0.69 & 0.69 & 0.002 & 0.500 & 0.487 \\
\hline
\end{tabular}

${ }^{\mathrm{A}}$ Diets: CT, control, with no additives inclusion; PRO, diet with $4 \mathrm{~g} / \mathrm{kg}$ of DM of probiotic inclusion; $\mathrm{CHI}$, diet with $4 \mathrm{~g} / \mathrm{kg}$ of DM of chitosan inclusion

${ }^{\mathrm{B}} \mathrm{C} 1$, contrast between $\mathrm{CT}$ and Additives; $\mathrm{C} 2$, contrast between PRO and $\mathrm{CHI}$.

\section{DISCUSSION}

Over the past few decades, pharmaceutical technologies, such as antibiotics, have been used in livestock production systems to improve animal performance and reduce production costs. The most consistent effect of antibiotics is the reduction of diseases, by improve the protection against bacterial disease and, consequently, stimulate growth rates. However, with the high consumer demand for antibiotic-free animal products, some alternative additives have been studied in animal production.

According to Yamani et al. (1992), that used a complex probiotic similar to the present study (Lactobacillus acidophilus, Streptococcus faecium, and yeasts) for rabbits, crude fiber digestibility improved at 8 and 12 weeks age, and it lead to the greater performance of rabbits fed PRO. Bhatt et 
al. (2017) also researching probiotic for growing Chinchilla rabbits, reported a greater feed conversion, average daily gain and final body weight of animals fed with Lactobacillus acidophilus and Lactococcus lactis. In addition, Oso et al. (2013) that worked with Prediococcus acidilacts and Bacillus cereus, reported improvements in the weight gains, feed conversion ratios, but not affected apparent nutrient digestibility values. However, these authors observed highest caecal lactobacillus with lowest coliform counts.

According to chitosan supplementation, Araújo et al. (2015) observed increase on rumen propionate $(7 \%)$ and reduction in acetate $(2 \%)$ proportion in steers fed chitosan. The authors explain that it can be associated with changes in the carbohydrate digestion without altering dry matter intake when chitosan was added in the rumen. Because of the effect of additives in performance traits, differences were also expected for serum metabolites by additives supplementation. Glucose concentration was reduced by $\mathrm{CHI}$ treatment compared to PRO animals, which could also represent an increase in muscle energy demand for growth in CHIsupplemented animals. Despite no statistical differences, animals fed PRO had lower ADG by 3\% compared to $\mathrm{CHI}$ group, suggesting greater energy demand for CHI animals to growth. The cholesterol was also affected by type of additives, in which animals fed PRO had a lower value than $\mathrm{CHI}$ supplemented animals. According to Pereira \& Gibson (2002) the probiotics have been related by their cholesterol-lowering effects and despite no sufficiently address the mechanisms by which probiotics act for this effect, several mechanisms have been hypothesized, which include enzymatic deconjugation of bile acids by bile-salt hydrolase of probiotics, assimilation of cholesterol by probiotics, cholesterol binding to cell walls of probiotics, incorporation of cholesterol into the cellular membranes of probiotics during growth, and production of shortchain fatty acids upon fermentation by probiotics in the presence of prebiotics (Ooi \& Liong, 2010).

As explained by Choi et al. (2012) and complemented by Anandan et al. (2013), in the stomach of non-ruminants chitosan acts as a cationic polysaccharide due to the acidic environment, causing the positive amino groups of the fiber to bind to negatively charged molecules, such as fatty acids. Although neutrally charged triglycerides are not affected, there is a reduction in plasma LDL levels (Santas et al., 2012). This gastric content, when it reaches the intestine and forms a complex composed of fatty acids, chitosan and bile acids in a higher $\mathrm{pH}$ environment, undergoes precipitation (Zhang et al., 2012). After precipitation, the bound fatty and bile acids are inaccessible to enzymes (Hossain et al., 2007), followed by the digestive tract and excreted in the faeces (Anandan et al., 2013).

For these reasons, in the present study the best fatty acid profile was presented by the animals that ingested chitosan and serum triacylglycerol concentration was increased in animals fed additives, and also was greater for animals fed PRO than CHI. The transport of triacylglycerols to target tissues is made via chylomicrons that, when reaching the tissue, are broken down by the lipoprotein lipase enzyme into glycerol and fatty acids to be absorbed and oxidized by the cells (muscles; (Nelson \& Cox, 2008). The increase in serum triglycerides in fed additives animals and in probiotic animals could indicate less necessity of fatty acids oxidation by greater energy metabolism, including greater propionate production for 
animals fed additive (Falcão-e-Cunha et al., 2007). Which could also explain the increase on meat protein and fat accumulation in animals fed with PRO compared to $\mathrm{CHI}$ in the present study by proximate analyses.

Regarding protein metabolites, the lower urea concentration on animal serum supplemented with additives may reflect a decrease of protein catabolism in skeletal muscle (Van Bibber-Krueger et al. 2015) or an increase in tissue nitrogen (N) deposition (Brake et al., 2011). It can also be observed by greater average daily gain and final body weight for animals fed additives than control group. According to Falcão-e-Cunha et al. (2007) the use of probiotics in rabbits improve the protein metabolism by decreasing ammonia production, increasing liver protein synthesis, and decreasing protein losses.

The color of the meat is the main attractive factor for the consumer at the time of purchase. The present data indicated that the red color was lower in the animals with CHI than in the PRO, in addition, the additives increased the yellowing and the luminosity of the meat in comparison to the control group. Meng et al. (2010) reported that meat color scores and redness values increased when pigs received the probiotics Bacillus subtilis endospore and Clostridium butyricum endospore complex. Along the same lines, Pelicano et al. (2003) also observed that the redness values in the meat of broilers increased in the groups treated with probiotics compared to the control group.

In measuring meat quality, water retention capacity, including drip loss and cooking loss, are crucial as meat quality determination, since some nutrients are easily lost during water loss exudation processes (Chen et al., 2012). In the present study, no effect of treatments were observed for WHC between treatments; however, the additives increased the CL and PRO had also greater CL and WBSF than CHI group. Contrary to the present data, Bai et al. (2017) reported lower CL and WBSF for broiler chicken fed PRO compared to the control diet. Park \& Kim (2014) concluded that dietary supplementation with probiotics $(B$. subtilis) in broiler diets increased the drip loss of breast meat after storage for one day, although the detailed reasons were unclear. Shear force was often expressed as the capacity for tenderness, and was one of the crucial sensory qualities that influenced the consumer. Zhou et al. (2010) reported that dietary $B$. coagulans exerted positive effects on the shear force of chicken breast meat. Pelicano et al. (2003) note that dietary probiotics in broiler diets was beneficial in meat quality by improving the $\mathrm{pH}$, tenderness, and color. However, the incongruities in results were due to the strains of probiotics, administration dosage, methods of preparation, bird age, diet composition, and hygiene status.

The fatty acid profile of the diet offered to rabbits is mainly composed of unsaturated fatty acids and the caecotroph fatty acids profile in indicate that additives improved the $\mathrm{C} 18: 1$ and $\mathrm{C}$ 18:2 on rabbits excretes, improving as well as the $\Sigma$ unsaturated, $\Sigma$ monounsaturated and $\Sigma$ polyunsaturated. It can be due to the microorganisms evaluated were able to changes and synthetize UFA. Lactobacilli strains have complex mechanisms by which different fatty acids are converted into shorter, longer, more saturated, or unsaturated fatty acids (Ross et al., 2012). There is evidence that low levels of oleic acid (18:1) in culture medium resulted in more lactobacillic acid and high levels resulted in higher amounts of dihydrosterculic acid. 
Standard rabbit meat is already a quite good source of unsaturated fatty acids (UFA) and linoleic acid, in the present study, it represents about $60 \%$ and $30 \%$ of total FAs, respectively, as consequence, rabbit meat can be effectively used to produce functional meat and meat products. Generally, the use of additives affects just a few FA on meat compared to the control group, increasing C 22:0, C 20:1, C 20:0, and the total FA, it can be probably because changes on fatty acid metabolism by additives supplementation as described above.

In addition, the $\mathrm{PRO}$ diet increased the $\mathrm{C}$ 18:2, $\Sigma$ unsaturated, Omega-6, UFA:SFA, and hypocholesterolemic index in meat. It can be due to two mean reasons, first because the composition of caecotroph, and second, because to the microorganisms evaluated were able to changes and synthetize UFA, as described above. This result indicate that probiotic can improve the meat healthily. In addition, the SFA:UFA ratio in the probiotic group meat was relatively close to the recommended ratio (Wood et al., 1999). Ross et al. (2012) fed pigs with probiotics, reported a decrease on $\mathrm{C}$ 14:0, SFA, and an improvement on $\mathrm{C}$ 18:3, CLA cis9-trans-11, MUFA and PUFA. The authors also explain that microorganisms evaluated were able to conjugate LA, increasing CLA, and PUFA.

\section{CONCLUSION}

The data showed that the probiotic treatment led a better meat quality, according fatty acids profile and hypocholesterolemic index compared to chitosan treatment. The additives improved the caecotroph fatty acid profile.

\section{REFERENCES}

ABDOU, A. M.; HEDIA, R. H.; OMARA, S. T.; MAHMOUD, M. A. E. F.; KANDIL, M. M..; BAKRY, M. A. Interspecies comparison of probiotics isolated from different animals.

Veterinary World, v. 11, n. 2, p. 227230. 2018.

https://doi.org/10.14202/vetworld.2018. 227-230

American Meat Science Association, A. Research guidelines for cookery, sensory evaleation and tenderness measurements of fresh meat (1st ed.). Chicago: American Meat Science Association. 1995.

ANANDAN, R.; GANESAN, B.; OBULESU, T.; MATHEW, S.; ASHA, K. K.; LAKSHMANAN, P. T.;

ZYNUDHEEN, A. A. Antiaging effect of dietary chitosan supplementation on glutathione-dependent antioxidant system in young and aged rats. Cell Stress Chaperones, v. 18, n. 1, p. 121125. 2013. httpsa://doi.org/

AOAC. Official Methods of Analysis. (15th ed). Arlington, VA: Association of Official Analytical Chemists. 2000. https://doi.org/10.1007/s12192-0120354-2

ARAÚJO, A. P. C.; VENTURELLI, B. C.; SANTOS, M. C. B.; GARDINAL, R.; CÔNSOLO, N. R. B.; CALOMENI, G. D.; FREITAS, J. E.; BARLETTA, R. V.; GANDRA, J. R.; PAIVA, P. G.; RENNÓ, F. P. Chitosan affects total nutrient digestion and ruminal fermentation in Nellore steers. Animal Feed Science and Technology, v. 206, p. 114-118. 2014.

https://doi.org/10.1016/j.anifeedsci.201 5.05.016

BAI, K.; HUANG, Q.; ZHANG, J., HE, 
J., ZHANG, L.; WANG, T.

Supplemental effects of probiotic Bacillus subtilis fmbJ on growth performance, antioxidant capacity, and meat quality of broiler chickens.

Poultry Science, v. 96, n. 1, p. 74-82. 2017.

https://doi.org/10.3382/ps/pew246

BHATT, R. S.; AGRAWAL, A. R.; SAHOO, A. Effect of probiotic supplementation on growth performance, nutrient utilization and carcass characteristics of growing Chinchilla rabbits. Journal of Applied Animal Research, v. 45, n. 1, p. 304309. 2017. https://doi.org/10.1080/09712119.2016. 1174126

BOKURA, H.; KOBAYASHI, S. Chitosan decreases total cholesterol in women: A randomized, double-blind, placebo-controlled trial. European Journal of Clinical Nutrition, v. 57, n. 5, p. 721-725. 2003. https://doi.org/10.1038/sj.ejcn.1601603

BRAKE, D. W., TITGEMEYER, E. C.; JONES, M. L. Effect of nitrogen supplementation and zilpaterol- $\mathrm{HCl}$ on urea kinetics in steers consuming cornbased diets. Journal of Animal Physiology and Animal Nutrition, v. 95, n. 4, p. 409-416. 2011. https://doi.org/10.1111/j.14390396.2010.01064.x

CHEN, H. X.; DONG, Z.; YAO, B.; XU, S.; ZHEN, C.; LI, X. Effects of prechilling parameters on water-holding capacity of chilled pork and optimization af prechilling parameters using response surface methodology. Journal of Animal Science, v. 90, n. 8, p. 2836-2841. 2012.

https://doi.org/10.2527/jas.2011-4239
CHOI, C. R.; KIM, E. K.; KIM, Y. S.;

JE, J. Y.; AN, S. H.; LEE, J. D.;

WANG, J. H.; KI, S. S.; JEON, B. T.;

MOON, S. H.; PARK, P. J.

Chitooligosaccharides decreases plasma

lipid levels in healthy men.

International Journal of Food

Sciences and Nutrition, v. 63, n. 1, 103-106. 2012.

https://doi.org/10.3109/09637486.2011. 602051

CHRISTIE, W. W. A simple procedure for rapid transmethylation of glycerolipids and cholesteryl esters.

Journal Of Lipid Research, v. 23, n. 7, p. 1072-1075. 1982.

CIE - COMMISSION

INTERNATIONALE DE L'ECLAIRAGE. Technical Report: Colorimetry ( $3^{\text {rd }}$ Edition). CIE15:2004. Retrieved from:

https://cielab.xyz/pdf/cie.15.2004\%20co lorimetry.pdf

FALCÃO-E-CUNHA, L.; CASTROSOLLA, L.; MAERTENS, L.; MAROUNEK, M.; PINHEIRO, V.; FREIRE, J.; MOURÃO, J. L.

Alternatives to antibiotic growth promoters in rabbit feeding: A review. World Rabbit Science, v. 15, n. 3, p. 127-140. 2007.

https://doi.org/10.4995/wrs.2007.597

FAOSTAT. (2015). Food and agriculture data.

GOIRI, I.; OREGUI, L. M.; GARCIARODRIGUEZ, A. Use of chitosans to modulate ruminal fermentation of a 50:50 forage-to-concentrate diet in sheep. Journal of Animal Science, v. 88 , n. 2, p. 749-755. 2010.

https://doi.org/10.2527/jas.2009-2377

HARA, A.; RADIN, N. S. Lipid extraction of tissues with a low toxicity 
solvent. Analytical Biochemistry, v. 90, n. 1, p. 420-426. 1978. https://doi.org/10.1016/00032697(78)90046-5 HOSSAIN, S., RAHMAN, A., KABIR, Y., SHAMS, A. A., AFROS, F., HASHIMOTO, M. Effects of shrimp (Macrobracium rosenbergii)-derived chitosan on plasma lipid profile and liver lipid peroxide levels in normo- and hypercholesterolaemic rats. Clinical and Experimental Pharmacology Physiology, v. 34, n. 3, p. 170-176. 2007. https://doi.org/10.1111/j.14401681.2007.04568.x

LI, S.; ZENG, W.; LI, R.; HO, L. C.; HE, Z.; SUN, Q. Rabbit meat production and processing in China. Meat Science, v. 145, p. 320-328. 2018.

https://doi.org/10.1016/j.meatsci.2018.0 6.037

MANCINI, S.; Minieri, S.; Buccioni, A.; di Cossato, M.M.F.; Russo, C.; Paci, $\mathrm{G}$. The influence of dietary chestnut and quebracho tannins mix on rabbit meat quality. Animal Science Journal, v.90, n.5, p.1-10, 2019.

https://doi.org/10.1111/asj.13194

MENG, Q. W.; YAN, L.; AO, X.; ZHOU, T. X.; WANG, J. P.; LEE, J. H.; KIM, I. H. Influence of probiotics in different energy and nutrient density diets on growth performance, nutrient digestibility, meat quality, and blood characteristics in growing-finishing pigs. Journal of Animal Science, v. 88, n. 10, p. 3320-3326. 2010.

https://doi.org/10.2527/jas.2009-2308

MILLER, R.; GRONINGER, S. Functional Properties O F EnzymeMod1 Fi Ed Acylated Fish Protein Derivatives. Journal of Food Science, v. 41, p. 268-272. 1976.
NELSON, D. L.; COX, M. M.

Lehninger Principles of Biochemistry

(W. H. Free). San Francisco. 2008.

OOI, L. G.; LIONG, M. T. Cholesterollowering effects of probiotics and prebiotics: A review of in Vivo and in Vitro Findings. International Journal of Molecular Sciences, v. 11, n. 6, p. 2499-2522. 2010. https://doi.org/10.3390/ijms11062499

OSO, A. O.; IDOWU, O. M. O.; HAASTRUP, A. S.; ALIBADE, A. J.; OLOWONEFA, K. O.; ALUKO, A. O.; OGUNADE, I. M.; OSHO, S. O.; BAMGBOSE, A. M. Growth performance, apparent nutrient digestibility, caecal fermentation, ileal morphology and caecal microflora of growing rabbits fed diets containing probiotics and prebiotics. Livestock Science. v. 157, n. 1, p. 184-190. 2017. https://doi.org/10.1016/j.livsci.2013.06. 017

OUWEHAND, A. C.; KIRJAVAINEN, P. V.; SHORTT, C.; SALMINEN, S. Probiotics: Mechanisms and established effects. International Dairy Journal, v. 9, n. 1, p. 43-52. 1999. https://doi.org/10.1016/S09586946(99)00043-6

PAIVA, P. G.; JESUS, E. F.; DEL VALLE, T. A.; ALMEIDA, G. F.; COSTA, A. G. B. V. B.; CONSENTINI, C. E. C.; ZANFERARI, F.; TAKIYA, C. S.; BUENO, I. C. S.; RENNÓ, F. P. Effects of chitosan on ruminal fermentation, nutrient digestibility, and milk yield and composition of dairy cows. Animal Production Science, v. 57, n. 2, p. 301307. 2015.

https://doi.org/10.1071/AN15329

PARK, J. H.; KIM, I. H. Supplemental 
effect of probiotic Bacillus subtilis B2A on productivity, organ weight, intestinal Salmonella microflora, and breast meat quality of growing broiler chicks.

Poultry Science, v. 93, n. 8, p. 20542059. 2014.

https://doi.org/10.3382/ps.2013-03818

PELICANO, E.; SOUZA, P.; SOUZA, H.; OBA, A.; NORKUS, E.;

KODAWARA, L.; LIMA, T. Effect of

Different Probiotics on Broiler Carcass.

Brazilian Journal of Poultry Science, v. 5, n. 3, p. 207-214. 2003.

http://dx.doi.org/10.1590/S1516-

635X2003000300009

PEREIRA, D. I. A.; GIBSON, G. R. Effects of consumption of probiotics and prebiotics on serum lipid levels in humans. Critical Reviews in

Biochemistry and Molecular Biology, v. 37, n. 4, p. 259-281. 2002.

https://doi.org/10.1080/1040923029077 1519

RAAFAT, D.; SAHL, H. G. Chitosan and its antimicrobial potential - A critical literature survey. Microbial Biotechnology, v. 2, 2 SPEC. ISS., p. 186-201. 2009.

https://doi.org/10.1111/j.1751-

7915.2008.00080.x

ROSS, G. R.; VAN NIEUWENHOVE, C. P.; GONZÁLEZ, S. N. Fatty acid profile of pig meat after probiotic administration. Journal of Agricultural and Food Chemistry, v. 60, n. 23, p. 5974-5978. 2012. https://doi.org/10.1021/jf205360h

SANTAS, J.; ESPADALER, J.; MANCEBO, R.; RAFECAS, M. Selective in vivo effect of chitosan on fatty acid, neutral sterol and bile acid excretion: a longitudinal study. Food Chemistry, v. 134, n. 2, p. 940-947.
2012.

https://doi.org/10.1016/j.foodchem.2012 .02 .211

TORRES, M.P. Capacidad de retención de agua. In: CAÑEQUE, V; SAÑUDO, C. Estandarizacion de las metodologias para evaluar la calidad del produto (animal vivo, canal, carne y grasa) em los rumiantes.

Madrid:INIA, p. 243-250. 2005

VAN BIBBER-KRUEGER, C. L.; MILLER, K. A.; PARSONS, G. L.; THOMPSON, L. K.; DROUILLARD, J. S. Effects of zilpaterol hydrochloride on growth performance, blood metabolites, and fatty acid profiles of plasma and adipose tissue in finishing steers. Journal of Animal Science, v. 93, n. 5, p. 2419-2427. 2015. https://doi.org/10.2527/jas2014-8771

WAHRMUND-WYLE, J. L.; HARRIS, K. B.; SAVELL, J. Y. Beef retail cut composition: 2. Proximate analysis. Journal of food composition and analysis, v. 13, n. 3, p. 243-251. 2000. https://doi.org/ 10.1006/jfca.2000.0896

WHEELER, T. L.; SHACKELFORD, S. D.; KOOHMARAIE, M. Shear force procedures for meat tenderness measurement. Animal Research, v. 1, n. 1, p. 1-7. 2005.

WOOD, J. D.; ENSER, M.; FISHER, A. V.; NUTE, G. R.; RICHARDSON, R. I.; SHEARD, P. R. Animal Nutrition and Metabolism Group Symposium on "Improving meat production for future needs" Manipulating meat quality and composition. Proceedings of the Nutrition Society, v. 58, n. 7, p. 363370. 1999.

https://doi.org/10.1017/S002966519900 0488 
YAMANI, K. A.; IBRAHIM, H.;

RASHWAN, A. A.; EL-GENDY, K. M.

Effects of a pelleted diet supplemented with probiotic (Lacto- Sacc) and water supplemented with a combination of probiotic and acidifier (Acid-Pak 4Way) on digestibility, growth carcass and physiological aspects of weanling New Zealand White rabbits. Journal

Applied of Rabbit Research, v. 15, p. 1087-1100. 1992.

YANG, H.; PARUCH, L.; CHEN, X.; VAN EERDE, A.; SKOMEDAL, H.; WANG, Y.; LIU, D.; LIU CLARKE, J. Antibiotic Application and Resistance in Swine Production in China: Current Situation and Future Perspectives.

Frontiers in Veterinary Science. v. 6, p. 136. 2019.

https://doi.org/10.3389/fvets.2019.0013 6.

ZHANG, H. L.; ZHONG, X. B.; TAO, Y.; WU, S. H.; SU, Z. Q. Effects of chitosan and water-soluble chitosan micro- and nanoparticles in obese rats fed a high-fat diet. International Journal of Nanomedicine, v. 7, p. 4069-4076. 2012.

https://doi.org/10.2147/IJN.S33830.

ZHOU, X.; WANG, Y.; GU, Q.; LI, W. Effect of dietary probiotic, Bacillus coagulans, on growth performance, chemical composition, and meat quality of Guangxi Yellow chicken. Poultry Science, v. 89, n. 3, p. 588-593. 2010. https://doi.org/10.3382/ps.2009-00319. 